\title{
Exploration on the Economic and trade Cooperation between Fujian and ASEAN under the Belt and Road Framework
}

\author{
Ju Ping \\ Fuzhou University of International Studies and Trade, \\ Fuzhou, Fujian 350202
}

\begin{abstract}
Under the historical background of "the Belt and Road", Fujian and ASEAN possess multi-aspect favorable conditions for industrial cooperation complementation. This paper mainly analyzes the bilateral trade conditions about Fujian and ASEAN in the recent years, and through collecting data, it studies the current economy and trade status of the two parties, analyzes the challenges and opportunities for the economic and trade cooperation between Fujian and ASEAN, and puts forward constructive suggestions and countermeasures, so as to deepen the development of Fujian and ASEAN in economic and trade cooperation, reinforce the economic and trade cooperation level of these two places, and drive the economic development of Fujian Province to become better and faster.
\end{abstract}

Keywords-The Belt and Road; Economic and trade cooperation; Industrial structure; Fujian and ASEAN

\section{INTRODUCTION}

During the state visit to Indonesia in October, 2013, General Secretary Xi Jinping firstly put forward the strategic concept of "the Belt and Road". As the important birthplace for Marine Silk Road, Fujian Province has the foundation and capacity to become the "leader" for promoting "the Belt and Road" strategy, but for Fujian Province, ASEAN is also an important trade partner, so Fujian Province should actively respond and actively integrate into new opportunities of the era, and then through the unique advantages of "geographical relationship", "popularity" and "historical origin", accelerate the promotion of strategic construction and implementation of Marine Silk Road.

\section{CURRENT STATUS OF THE ECONOMIC AND TRADE COOPERATION OF FUJIAN AND ASEAN}

\section{A. The Bilateral Trade Volume for Fujian and ASEAN is Stably Increased}

The economic and trade cooperation between Fujian and ASEAN has started a long time ago, and the economic and trade cooperation has been constantly increased, but the increase speed has shown down; according to the statistics of customs in Fuzhou, from 2011 to 2015, the trade volume of Fujian Province for ASEAN was increased to USD 25.52 billion from USD 18.33 billion, presenting a relatively stable increase trend; besides, in 2014, being benefited from the advantages of the concept of "the Belt and Road", it reached to the peak value of USD 25.68 billion. The economic and trade cooperation between Fujian and ASEAN is generally focused on trade mode, and according to the statistic data from 2014 to 2016: the general trade volume for Fujian and ASEAN was respectively USD 12.75 billion, USD 12.41 billion and USD 12.43 billion in total, which respectively occupied above $70 \%$ of the total trade value for Fujian and ASEAN in the same year [1].

\section{B. The Industrial Cooperation Between Fujian and ASEAN has Complementarity}

1) Current Status about the Industrial Development of Fujian

The industrial reform of Fujian Province was started late, and throughout the ages, labor intensive industries have always taken lead in Fujian Province, but along with the constant adjustment of industrial structure, it has been improved. The ratio for the first industry in Fujian Province was decreased to $8.3 \%$ in 2016 from $16 \%$ in 2001 , with obvious decrease amplitude; the second industry presented a constant increase trend as a whole, and was increased to $48.8 \%$ in 2016 from $44.3 \%$ in 2002, with stable increase amplitude; but the rate for the third industry was $42.9 \%$ in 2016. But the regional development in Fujian is unbalanced, and the economic development in Fuzhou, Xiamen, Zhangzhou and Quanzhou was fast; but the industrial institutions in Longyan, Sanming, Nanping and other regions remains to be adjusted, so in the future, Fujian should further optimize the regional industrial structure and promote industrial development.

2) Current Status about the Industrial Development of ASEAN

There is certain difference in the industrial structure of various ASEAN member countries, and it can be regarded as "pyramid type" in general; Singapore, Brunei and Malaysia are on "the top of the tower", and these three countries are on the top of regional economy and industrial structure, and the science \& technology intensive industries are relatively developed in these countries, and the service industry can occupy or will transit to the leading position; Thailand, Indonesia, and Philippine are located at "the tower body", and these three countries are approximately located at the middle period of industrial development, and the industrial 
development level has begun to take shape, and the high-tech industrial development is fast, but relies on the support of natural resources; Vietnam, Laos, Burma, Cambodia and other countries with backward economic level are located at "the bottom of the tower", and these countries are focused on agricultural production and the export of agricultural products, and the industrial foundation is relatively weak, but there are still a considerable development and climbing space[2].

In general, the difference for various ASEAN member countries is relatively obvious in economic development, and the economic strength presents the trend of polarization, and the difference in the development level of industrial structure is also bigger. However, although Fujian is located at the southeastern coastal areas, and it was opened to the outside world earlier and the economy is relatively developed, the regrettable thing is that the industrial structure adjustment in Fujian is relatively late, so the industrial structure for various regions within Fujian Province also has obvious difference, so Fujian and ASEAN have industrial structure complementarity.

\section{OPPORTUNITIES AND CHALLENGES FACED IN THE} ECONOMIC AND TRADE COOPERATION OF FUJIAN AND ASEAN

\section{A. Opportunities}

\section{1) The Geological and Cultural Advantages in Fujian} Province are Obvious

Fujian Province is located at southeast coastal areas, and is the important birthplace for the ancient "Marine Silk Road", with many seaports and long coastal lines; it is neighboring Taiwan Strait and South China Sea in the east and south respectively, and is also the important airline for the marine trade of east areas. Meanwhile, Fujian Province has been established as "the Core District for Marine Silk Road of the 21st Century" as well as the bridgehead and forerunner for the strategic concept of "the Belt and Road". Secondly, as the important birthplace of the ancient Marine Silk Road, Fujian Province has a long association history with countries along the line, while Fujian has many overseas Chinese residing in South Asia, and above 9 million people therein live in South Asia. Moreover, Fujian merchants have strong strength, and big economic influence in South Asia; Mazu Culture has a profound influence in local, and all of these popularity advantages, geographic advantages and capital advantages are the unique advantages for Fujian to integrate into the Marine Silk Road of the 21 st Century.

2) Fujian and ASEAN have a Long Economy and Trade Exchange History and Profound Foundation

The association history between Fujian and ASEAN can be traced back to Han Dynasty. Since the reform and opening-up, the trade relationship between China and ASEAN has kept its powerful momentum of increase, and China has already firmly occupied the title of the biggest trade market in ASEAN, and Fujian has also become the fourth import market and the second export market of ASEAN. Along with the start of CAFTA construction, CAFTA cooperation upgrading was realized in 2011, and then the strategic concept of "the Belt and Road" was implemented, and Fujian Free Trade Park was listed and established. In the bilateral trade with ASEAN, Fujian
Province not only possesses a long historical restriction but also obtains a series of political promotion, and the economic and trade cooperation between Fujian and ASEAN has entered into a brand new golden period, which can be an unprecedented opportunity for the economic and trade relationship between Fujian and ASEAN [3].

\section{B. Challenges}

1) The Exported Commodities of Fujian are Focused on Labor Intensive Type, with Low Additional Value

As can be seen from the data analysis, Fujian Province merely exported mechanical and electrical products, agricultural products and textile manufactured products to ASEAN, of which the agricultural products and textile products are all labor intensive commodities, with low scientific and technical contents, and low additional value of commodities, and they are all traditional products with relatively weak brand popularity; while mechanical and electrical products mainly focused on being engaged in the terminal processing package of the industrial chain, without mastering the core technology, and the market competition is focused on price. Due to relatively small profit space, it is relatively difficult for enterprises to provide comprehensively sound service for foreign trade, after-sales link and other aspects, except sales. Secondly, the various ASEAN countries are also mainly engaged in the export of labor intensive industries, and there is homogeneous competition in aquatic products, agricultural and sideline product processing and other highly coincident industries. The construction of "the Belt and Road" is also "a double-edged sword" for Fujian Province, for instance, "Nike" company recently moved its production base from Fujian Province to Vietnam.

2) There are Differences in the Trade Barrier of Various ASEAN Member Countries

The industrial structure for various ASEAN member countries presents "pyramid type" unbalanced development status among all countries, and not all countries can possess good investment and trade environment; in the foreign trade of Fujian for ASEAN, Brunei, Cambodia, Laos, and Burma are under a relatively "inferior" position, and the reason is mainly as follows: Cambodia, Laos, and Burma belong to undeveloped countries; however, although Brunei is a developed country, the country is small with few population; besides, there is a huge difference in the standard of various ASEAN member countries in laws restriction and the implementation of relevant trade barriers, and some countries don't recognize the product quality inspection report of China; the measurement unit adopted by some countries is different from that of our country, and all of these factors are the reasons restricting the bilateral trade between Fujian and ASEAN [3]. 
IV. COUNTERMEASURES FOR DEEPENING THE ECONOMIC AND TRADE COOPERATION OF FUJIAN PROVINCE AND ASEAN

\section{A. Fully play Chinese Merchant Resources, and Energetically Exploit the ASEAN Market}

As can be seen from the relevant data, in the annual bilateral trade volume between Fujian and ASEAN, the total trade volume for Malaysia, Indonesia, Singapore, and Philippine occupies above $70 \%$. But for other ASEAN countries, it is requested to further reinforce development; as the famous hometown for overseas Chinese, Fujian Province has a long economic and trade communication foundation with ASEAN countries due to the close geographical relationship, and religious cultural convergence as well as the fact that Fujian had a big batch of overseas Chinese living in the South Seas. The overseas merchants residing in the South Seas are the invisible resources that cannot be neglected for the in-depth economic and trade contact between Fujian and ASEAN, and the Southeast Asian Chinese with rich capital can become the forerunner and bellwether for Fujian and ASEAN to further deepen regional cooperation strength. Fujian Province should energetically utilize the interpersonal resources of overseas Chinese, reinforce the contact with Chinese merchants of Chinese enterprises in Southeast Asia, and then use Fujian Natives Association for overseas Chinese living in various ASEAN countries, fully use the commercial channel of overseas Chinese and Chinese merchants, the interpersonal relationship collection and operation advantages thereof to guide them to participate in the practice of "Marine Silk Road" strategy. Build a bridge for Fujian Province to exploit the trade market of Cambodia, Burma, Laos, Brunel and other countries, fully play the advantages as the hometown of overseas Chinese, expand the economic and trade contact with ASEAN, and make it become the stable collaborative platform in the bilateral trade between Fujian and ASEAN.

\section{B. Pointedly Develop Science and Technology, and Implement the Strategy of Reinvigorating Trade by Science and Technology}

As can be seen from data analysis, the exported products of Fujian Province are mainly labor intensive commodities, with relatively low additional value of product, and price is regarded as the only advantage for expanding the market and competing with similar products, with relatively low profit rate. In order to better implement the concept of "the Belt and Road", Fujian Province should emphasis on developing science \& technology intensive industries, establish the driving force that takes science and technology as the economic core, accelerate the optimization upgrading of industrial structure, and meanwhile, improve the scientific and technical contents of traditional commodities, constantly promote the position in international division of labor; secondly, energetically cultivate high additional value products with proprietary intellectual property rights, and independent R\&D capacity, regard these products as the export emphasis, release relevant policies for protection, use quality to replace quantity, and improve market competitiveness. Thirdly, upgrade the industrial structure of the exporter, for instance, the shoes and cloth industry in Quanzhou should gradually get rid of the agent processing, establish and support self-owned brand, actively conduct R\&D and introduce the technology for fabric production and shoes production, and fully utilize the existing channels in the marketing link, and boldly innovate; besides, the government should also periodically organize the product expo of relevant industries, invite domestic and overseas merchants and international brand to help the local enterprises to exploit the international market [4].

To sum up, while Fujian Province maintains the existing position in ASEAN and the international market, it should also work hard to promote the reform of industrial structure, support scientific and technical enterprises with proprietary intellectual property rights, promote the scientific and technical competitiveness of our province, accelerate the upgrading of traditional enterprises, so as to improve the industrial cooperation depth for Fujian and ASEAN.

\section{Implement Differential Treatment and Adopt Differentiated Industrial Cooperation Strategy}

According to the research analysis, the economic development degree in ten ASEAN countries presents the trend of three-level differentiation, and the difference in industrial structure is also very obvious. The economic development conditions in various ASEAN member countries present "pyramid type", so in the actual economic and trade cooperation, our province should adopt differential trade strategies as per the similarities and differences about the characteristics of various countries.

For instance, in the industrial cooperation with Singapore, the emphasis should be the high-tech industry, finance, air shipping, port logistics and other modernized service industry, and Singapore has rich technical resources and talent reserves and is also the important hub port for marine transport and also the world's oil refining center, but it is short of agricultural basis, and the industrial department is mainly the shipbuilding and petroleum industry, so the export emphasis should be mechanical equipment and agricultural products, and the import should focus on high-tech and service field; for Malaysia, Indonesia, Thailand and other developing countries, it is requested to mainly conduct industrial complementation, promote advantage complementation and economic cooperation, for instance, it is applicable to import qualified agricultural products and tourism service from Thailand, and output textile, shoes, clothes and other light industrial products; as for Laos, Burma, Cambodia and other under-developed countries, the emphasis should be investment, and the output of capital and technology, and meanwhile, it is applicable to reasonably use the resources, labor force, raw material advantages of these countries to develop labor intensive industries, promote mutual benefit, and actively expand the space for commerce and trade [5]. 


\section{Reasonably use Political Advantages, and Expand the Overseas Trade with Various ASEAN Countries}

When being compared with other provinces and cities nationwide, the trade advantages for Fujian and ASEAN are mainly focused on the marine trade. Thus, in the process for Fujian Province to implement the concept of "the Belt and Road", it is requested to pointedly expand the marine trade cooperation with various ASEAN countries. There are three main suggestions: firstly, it is requested to upgrade the infrastructure for various ports of our province, and the perfection of advanced infrastructure is the "confidence" for conducting marine trade and port-shipping cooperation; secondly, it is requested to energetically promote the formulation, release and implementation of a series of preferential policies about the marine trade and port cooperation between Fujian and ASEEAN, so as to reinforce the attraction of various ports in Fujian for various ASEAN countries, and make it become the solid barrier for the bilateral trade between Fujian and various ASEAN countries. Thirdly, it is requested to establish and optimize the service system in foreign trade and port logistics, etc., and make the bilateral trade more convenient, and also attract powerful ASEAN enterprises to establish long-term stable and solid cooperation relationship. Finally, it is requested to reinforce the interaction and docking with countries along "Marine Silk Road", and create it into the important hub port on the "Marine Silk Road" [6].

\section{CONCLUSION}

To sum up, under the historical background of the implementation of "the Belt and Road", Fujian Province should affirm ASEAN region as the main attack direction and key region for Fujian to establish the core district of "Marine Silk Road", and then by virtue of popularity advantages, geographic advantages, business website advantages and political advantages, flexibly apply differential trade strategies through the active adjustment and optimization of industrial structures, energetically support series of methods for foreign trade enterprise, work steadily and step by step, work hard to promote the economic and trade cooperation of Fujian and ASEAN to become better and faster.

\section{ACKNOWLEDGMENT}

"Supported by the Training Program of Fujian Excellent Talents in University" in English, and "FETU" for short); Chinese International Trade Association Topic in 2017 (2017MYXHZX007)

\section{REFERENCES}

[1] Research Group of Fujian Academy of Social Sciences. Research about the Countermeasures for Deepening the Economic and Trade Relationship between Fujian and ASEAN under the Framework of CAFTA [J]. Asian-Pacific Economy, 1000-6052. 2010, 06, 020.

[2] Tang Fan and Tao Hongjun. Analysis on the Trade Competitiveness of Fujian for ASEAN under the Condition of CAFTA - Taking Four ASEAN Countries as the Example [N]. Journal of Fujian Agriculture and Forestry University (Philosophy Social Science Version), 2009, 12(2): 55-59.

[3] Wu Chongbo. Advantages, Challenges and Countermeasures for Fujian to Construct 21st Century of Marine Silk Road Strategy [J]. AsianPacific Economy, 1000-1052 (2014) 06-0109-05.

[4] Xiu Juhua. Research about the Current Status of Economic and Trade Cooperation between Fujian and ASEAN and the Countermeasures [N]. Journal of Changsha University. 1008-4681(2016) 03-0027-03.

[5] Research Group of Fujian Academy of Social Sciences. Research about the Current Status of Trade between Fujian and ASEAN and the Development Trend [J]. Asian-Pacific Economy, 2010, Period 6.

[6] Cai Qiuhong and Zhuang Peifen. Analysis on the Export Competitiveness of Aquatic Products in Fujian Province [J]. Journal of Fujian Agriculture and Forestry University (Philosophy Social Science Version), 2011 (1): 34-38 